\title{
Writing Ability Improvement on EFL Students Using Think Pair Share Technique
}

\author{
Nisrina Balqis Huwaida \\ Universitas Muhammadiyah Jember \\ (nisrina.balqis95@gmail.com)
}

\begin{abstract}
This research was to find out the effective way using think pair share technique to improve the students' ability in writing analytical exposition text. The design of this research is Classroom Action Research. The research subject is XI B class consisting of 30 students. The data collected by using writing test, field note and documment. In order to analyze the data students' writing score, percentage formula is used. The researcher used only one cycle which consist of two meetings. Those the result of this cycle achieved the criteria of success. Think Pair Share technique improved the students' writing ability in one cycle from the percentage of the students' score $\geq 75$ ( $E=83 \%$ ). It is concluded that Think Pair Share Technique can improve the Eleventh grade students' writing ability at Islamic Boarding School Baitul Arqom in the 2016/ 2017 academic year by involving the students working in pair and sharing the ideas. So that they can discuss their writing draft and revise the writing product.
\end{abstract}

Keywords: Writing ability, Think Pair Share technique.

Writing is a developmental process. Students try to express their views or ideas in the best writing with teachers' guidance. Grenville (2001, p. 6) stated that writing is a process. No one is born knowing how to write, but it is a skill that most people can learn. The difficulty in writing is not only in developing and organizing ideas, but also in translating these ideas into readable text. Hyland (2004: 09) explained that writing is a way to share personal meanings. The people construct their own views on topic. They will share their views on a topic to each other then. A person's views may be different from other people's views. It depends on their belief. Therefore, when constructing their views (ideas), the people have to make it understandable and acceptable. It means that the students need a partner to share their ideas.

The eleventh grade students should be able to write or produce analytical exposition text. Since they produce analytical exposition text, they face difficulties in developing ideas into good order to form a good analytical exposition paragraph and in organizing structure of the text.

Based on the classroom observation, most of the students could arise ideas but they found it difficult to express it in writing form. The teacher usually provided the students some individual activities. So, based on this preliminary study it is only $40 \%$ of the students got $\geq 75$ in score.

Harmer (2004, p. 128) stated that pair work plays an important role in a big class. They can maximize students' participation. To make the students motivated and enjoyable in learning, the teacher should use interesting technique. One of the techniques in cooperative learning is Think Pair Share (TPS). Arends (2007, p. 354) stated that Think Pair Share is an effective way to change the discourse pattern in a classroom. It challenges the assumption that all recitations or discussions need to be 


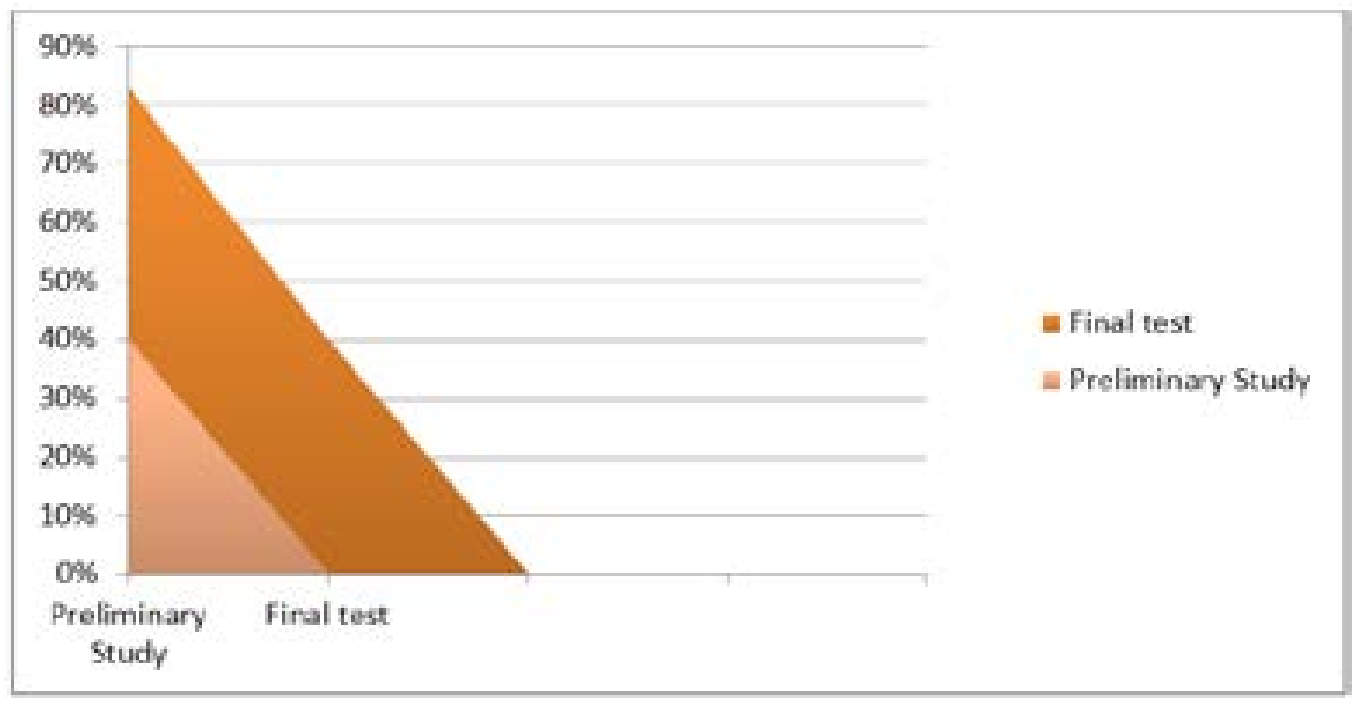

Figure 1. Student's score from preliminary and final test

held in whole group setting, and it has been built in procedures for giving students more time to think and to respond and to help each other. Students have the opportunity to share their ideas and share their mistakes into their pair. For that reasons, the writer brings think pair share technique to involve students in learning writing an analytical exposition text.

\section{Method}

This is Classroom Action Research (CAR). The subject of this research is the Eleventh grade student at Islamic Boarding School Baitul Arqom Balung which consists of 30 students of XI B Class. The instruments of this research are writing test, field note, and document.

In test, the students are asked to write an analytical exposition text in paragraph in 60 minutes, 200 words. There are three topic provided by the teacher. The observer used field notes to write down the activities during teaching and learning process in the classroom. The aspects observed in the field notes are as follows: how the teacher implements Think Pair Share Technique in teaching writing in the classroom, how the students respond in writing analytical exposition text which has been taught through Think Pair Share Technique, and how the improvement and the development of the students' test between the first meeting to the last meeting are.

Document provides students' writing analytical exposition draft. These documents are from students' writing assignment starting from the first meeting to the third meeting in one cycle to know their improvement.

\section{Results and Discussion}

Based on the field note in the first meeting to the last meeting, the students' responses from the first meeting to the last meeting were really improved. They were enthusiastic in receiving the material from the teacher through TPS technique. The students were also more active in asking some questions and gave their partner feedback. They shared their ideas into a whole class and the others corrected it if there was a mistake.

Based on the test, there were 25 students of 30 students who got $\geq 75$. In other words, the target criteria of this research - 83\% - was achieved. It can be seen in Figure 1.

The eleventh grade students were working in a small discussion rather than working individually in teaching and learning process, because they need a feedback from the others especially in composing analytical exposition text. Hyland (2003, p. 44) stated that the concept of writing was great if it was done by doing discussion with a partner. 
By understanding their writing together, students are better able to interpret, produce and critique the texts they have to write.

There were three steps in doing TPS technique: Think, Pair and Share. In Think phase, the students had to choose one of the following topics which was given by the teacher and began to write some points related the topic that had been chosen by the students individually. This phase can impact to the students in developing their ideas before arranging the sentences in writing analytical exposition text, because they forced to think and transformed their ideas into some points on a paper. Firstly the students wrote the main ideas to make them easly focus on. The students focused on their argumentations and it must be related with the main idea. It can be pros or contras. The students had to make the argumentations related the topic to make the reader convince with the writers' argument.

In Pair phase, the students worked in pair with their friends. This step needs alot of times. So the students were asked to work with their partner who sitting beside them without exchanging the students rondomly. The students would not find a different topic in their pair. They began to discuss with their pair about the topic that had been choosen and some points which was written. They worked in pair in composing analytical exposition text. This phase could provide to the students in working cooperatively to reduce or add the argumentations related to the points that had been already written. Brown (2001, p. 336) identified that writing as the process of putting ideas down on paper to transform thought into words, to sharpen your main ideas, to give them structure and coherent organization.

In Share phase, the students shared their ideas briefly based on the main ideas and also their argumentations of the topic they wrote. This phase could improve their responsibility in sharing their product to the others. In short, the students' writing were significantly improved because they had to think clearly and choosed sentences logically and put ideas down on paper to transform the thought into words, to sharpen main ideas, to give them structure and coherent organization and to convince the readers that there was an issue need to get attention, because the purpose of analytical exposition itself to convince the readers with the writers' argumentations.

Based on the result of observation in this cycle, it was found that the students did not primarily understand well about analytical exposition text. Then, the teacher gave explanation to the students. The students could ask some questions related to the material until they understood it well. In the second meeting, it was found that the students understood about the material and begun to compose analytical exposition text using Think Pair Share Technique. They were also able to make an analytical exposition text better than what they did previously because this technique allows the students to think cooperatively with their partners.

\section{Conclusion}

It is concluded that Think Pair Share Technique can improve the Eleventh grade students' writing ability at Islamic Boarding School Baitul Arqom in the 2016/ 2017 academic year by involving the students working in pair and sharing the ideas. So that they can discuss their writing draft and revise the writing product.

In having good writing never a one step action, it is an on going creative act. Think phase influenced to the students in developing ideas and made the students easily in arranging the sentences in order. By putting the ideas down on paper to transform thought into words, to give them structure and coherent organization and to convince the readers that there was an issue need to get attention. Those are influenced in pair phase, because it is the main activity to develop their writing beside Think and Share phases. On the other hand, Share phase also needed to share what had been written by the students in a whole class to make the writers proud of their product. 


\section{References}

Ali, M. (1993). Strategi Penelitian Pendidikan. Bandung: Angkasa.

Arends, R. (2007). Learning To Teach. New York: Mc Graw Hill Companies, Inc.

Arikunto, S. (2010). Prosedur Penelitian Suatu Pendekatan Praktik. Jakarta: PT RINEKA CIPTA.

Ary, D., et al. (2010). Introduction to Research in Education Eighth Edition. Canada: Cengage Learning Products.

Brown, H. D. (2011). Teaching by Principles An Interactive Approach to Language Pedagogy 2nd Edition. Longman: Pearson Edition.

Brown, K. and Susane H. (1989). Writing Skills and Strategies for Students of English. New York: Cambridge University Press.

Elbow, P. (1998). Writing with Power: Techniques for Mastering the Writing Process. Oxford University Press: Oxford New York.

Grenville, K. (2001). Writing From Start to Finish a Six-Steps Guide. New South Wales: Allen \& Unwin.

Harmer, J. (2004). How to Teach English. Pearson Education Limited.

Heaton, J. B. (1988). Writing English Language Tests. New York: Longman.

Hedge, T. (1988). Writing. London: Oxford University press.

Hughes, A. (1981). Testing for Language Teachers. New York: Cambridge University Press.

Hyland, K. (2003). Second Language Writing, New York: Cambridge University Press.

Ledlow. S. (2001). Using Think Pair Share in the Collage Classroom. Center for Learning Excellent.

Moleong, L. J. (2014). Metodologi Penelitian Kualitatif Edisi Revisi. Bandung: PT Remaja Rosdakarya. 